\title{
Thermal Discomfort in the School Workshop as a Stress Factor Affecting students' Tasks Performance in Workshop Practice
}

\author{
Japo O. M. Amasuomo (Ph. D.) \\ Department of Vocational/Industrial Education, Niger Delta University, Wilberforce Island, \\ P. O. Box 1033, Yenagoa, Bayelsa State, Nigeria. \\ Email:japoamasuomo@gmail.com
}

Alexander U. Onyia (Ph. D.)

Department of Technology and Vocational Education, Enugu State University of Science and Technology, Agbani, Enugu State, Nigeria

\section{Doi:10.5901/ajis.2014.v3n4p465}

\section{Abstract}

The study investigated students' perception of thermal discomfort in the school workshop as a factor affecting their task performance in workshop practice. The participants were 183 NCE Technical Education students that comprised 73 and 112 students in 300 Level from Federal Colleges of Education (Technical), Asaba and Omoku, Nigeria respectively during the 2008/2009 academic session; there was no sample. The Thermal Discomfort Perception and Task Performance Questionnaire (TDPTPQ) were used to collect data. Reliability of the instrument was, (0.85); and the Arithmetic Mean, Standard Deviation; and the Z-test at $P \leq 0.05$ were used to analyze the data. The perceived thermal discomfort indicators were mental fatigue (lack of concentration), physical fatigue (tiredness), inattentiveness, non-vigilance and restlessness. The students perceived that these indicators affected their task performance in slow 'use-output'; reduced cognitive and perceptual motor; and precision tasks; reaction time, and other tasks requiring greater attention. No significant difference existed in the mean response scores of students from the two colleges in their perception of thermal discomfort indicators as factors affecting their task performance in workshop practice. It was recommended that, the negative effects of thermal discomfort in school workshops be reduced to enable students effectively their task performance in workshop practice.

Keywords: thermal, discomfort, indicators, perceived, affect, task, workshop, performance, fatigue, reaction time

\section{Introduction}

Thermal discomfort as stressor occurs in a room space when there is high temperature and relative humidity; and low wind velocity. Temperature, which is the degree of hotness, or sensible heat or coldness in a body or the atmosphere (Anyakoha, 2006) could generate heat and activate the sweat glands that produce moisture in the body of individuals. Further, temperature increase above individual's tolerable limit can increase sweat production of the body especially during rigorous activities. The feeling of increase in sweat production creates body heat and a 'wettedness' sensation at high humidity (Markus and Morris, 1980). The heat production in a room space is between 235 and 440 per person (Adler, 1997) and the amount of vapour liberated is about 0.2 per person per hour (Burberry, 1997) when various physical activities rated light or heavy are carried out. Any room space that does not have adequate provision for ventilation becomes hot and uncomfortable for the occupants especially with high external and internal temperature because of the cumulative effect of the heat that is generated and sweat (vapour) liberated by its occupants.

Humidity is moisture, damp or moderate degree of water vapour content in the air at a given temperature (Bridger, 2003; and Anyakoha, 2006). High relative humidity affects the thermal comfort of individuals in a room space especially when vapour liberated through perspiring occupants carrying out various human activities is not evaporated as frequently as possible. Discomfort is experienced because of the inability of the occupants to dissipate metabolic moisture (Yellot, 2008). At high humidity, the undesirable side effects are dampness or 'wettedness' sensation and sometimes difficulty in breathing (Markus and Morris, 1980; and Anyakoha, 2006), while at low humidity the discomfort experienced is dehydration or dryness in the nose, throat and the skin as well as clapped lips (Anyakoha, 2006). Therefore, in extreme conditions of humidity; that is either too high or too low should be avoided since it will lead to other undesirable side effects. In this regard, Ayoade (2002) reported that, when the air is humid, evaporation of perspiration from the body is 
limited and a feeling of oppression so common in the humid tropic is created.

Wind is air in motion or breeze or air that moves quickly as a result of natural forces (Hornby, 2006) and it is essential for the feeling of freshness and comfort in any room space. Air movement plays an important role in increasing the rate of evaporation, especially at high humidity where evaporative cooling is the only or main means of heat loss from the body (Markus \& Morris, 1980). Wind reduces the adverse effects of thermal discomfort resulting from high temperature and humidity. If the air is calm, the air layer close to the body becomes more or less saturated and little or no further evaporation takes place. But where there is considerable air flow; the constant replenishment of air around the body ensures that the evaporation process is maintained (Ayoade, 2002). The availability of fresh air in a room space serves three purposes namely to supply adequate level of oxygen for breathing; to dilute odours arising from bodies or industrial process; and to dilute air vitiated with bacteria (Markus and Morris 1980). Where the three purposes of air are not met, people will feel thermal discomfort in any given space.

In this study thermal discomfort is a stressor that impinges and threatens the well-being of a person while stresses are the various reactions of an individual to the effect of the stressor (Bell, Greene, Fisher \& Baum, 2005). The observable stress related behaviours of an individual from thermal discomfort as a stress factor are mental fatigue (lack of concentration), physical fatigue physical fatigue (tiredness), inattentiveness, non-vigilance and restlessness which occur due to sweating and heat exhaustion (Sanders \& McCormick, 1993; and Bridger, 2003).

Sweating is caused by high temperature and humidity and low wind velocity. Sweating is a means of defence against heat stress when the body looses heat by evaporation. In the humid tropics, sweat evaporation diminishes and cooling efficiency is lost even when sweat is continually produced. Profuse sweating and continuous exposure to high temperature may lead to dehydration (loss of water and salt), inattention, restlessness, etc and reduces endurance for physical works (Sanders \& McCormick, 1993; and Bridger, 2005).

Heat exhaustion occurs when there is increased stress on various body organs because of excessive perspiration and strenuous physical exertion (Kavianian \& Wentz, 1990; and Hammer \& Price, 2002); and the body carries inadequate heat to the skin and certain critical areas are deprived of blood leading to excessive demand for blood by the circulatory system (Bell, Fisher, Greene and Baum, 2005; and Price and Hammer, 2002). The symptoms of heat exhaustion are faintness; dizziness, headache, muscular weakness, restlessness, heavy sweating, mental and physical fatigue, irritability and drowsiness (Kavianian \& Wentz, 1996; Sanders \& McCormick, 1993; Hammer \& Price, 2002; Greene, Fisher \& Baum, 2005; and Jain \& Rao, 2006).

Human stress maladies from thermal discomfort in a room space should therefore be avoided. From the foregoing, Yaglou (1968) described thermal comfort as a condition under which a person can maintain a normal balance between production and loss of heat at normal body temperature without sweating. Markus \&Morris (1980) described thermal comfort as a state a person will judge the environment to be neither too warm nor too cold or thermally neutral, and in this condition, the strain on the body's thermoregulatory mechanism is minimal. That is, thermal comfort is a state a person will judge the environment to be neither too warn nor too cold; a neutral point defined by the absence of any feeling of discomfort. Givoni (1981) defined thermal comfort as the absence of irritations and discomfort due to heat or cold, or in a positive sense, as a state involving pleasantness. Fanger (1982) stated that, thermal comfort is that condition of mind which expresses satisfaction with the thermal environment. Further, Dagostino (2004) defined thermal comfort as being able to carry on any desired activity without being either chilly or too hot.

Establishing a condition that will satisfy everyone is not likely to be achievable because of human physiological variance. Rather, the internal environment should be able to create conditions that can satisfy the largest number in the group of probable occupants. That is, a building envelope should be able to modify the internal environment into a space conducive for human activities for majority of the users.

Thermal discomfort has negative consequences for task performance and unsafe behaviours in workplace. Optimal performance of task in a thermal environment is gingered by motivation and reward. However, motivation and reward itself may not produce optimal performance but other intervening variables such as temperature, relative humidity and air movement which brings about thermal comfort or discomfort may also affect performance positively or negatively. However, no two individuals react in the same way in a thermal environment in the same workshop space due to variation in age, state of health, physical activities, type and amount of clothing, physique of the individual and the degree of acclimatization (Ayoade, 2002, and Chardderton, 2007). Optimal performance of task in a thermal environment therefore, depends on exposure conditions, body temperature, and metabolic cost of physical activities, motivation and reward, acclimatization, skill levels of the subjects used, the nature of the tasks performed, and the stress from heat effect (Bell, Greene, Fisher, \& Baum, 2005).

Thermal discomfort therefore has a profound effect on the performance of physical and mental tasks. It affects 
performance of physical tasks since most workshop activities require physical exertion that dissipates energy. Physiological discomfort from climatic factors creates competition for blood between the working muscles and the skin. This may lead to exhaustion in heavy physical task and performance decrement occurs sooner in a hot environment (Sanders \& McCormick, 1993).

Thermal discomfort affects performance of mental task indirectly because the stress which affects individuals physiologically, also affect their performance (Bridger, 2003). Some of the mental task performances affected by thermal discomfort are simple cognitive and perpetual-motor tasks; low 'use-output'; precision tasks; reaction time, and other tasks requiring greater attention (Sanders and McCormick, 1993; Bridger, 2003; and Bell, Greene, Fisher, and Baum. 2005). Further, thermal discomfort also increases unsafe behaviours during task performance. According to Ramsey, Burford, Beshir \&Jensen (1983), the ratio of unsafe behaviours increases at either above or below $17{ }^{\circ} \mathrm{C}$ to $23^{\circ} \mathrm{C}$ wet bulb globe temperature. That is, when climatic conditions are below or above this preferred range, the incidence of unsafe behaviour increases.

In the same vein, stresses from thermal discomfort have adversely affected individuals' attitude to work and performance in both physical and mental tasks, the speed of accomplishment of such tasks when the stress becomes intense beyond tolerable limit of the individual (Markus and Morris, 1980). The degree to which the thermal discomfort stresses affect the individuals' performance also varies according to the intensity and ability of the individual to withstand stresses induced by these environmental stressors.

From literature, it has been established that thermal discomfort affected the performance of individuals' in both physical and metal tasks. This necessitated the need to find out whether students in a school workshop will also perceive thermal discomfort as a stress factor that will affect their task performance in workshop practice especially at the Nigerian Certificate in Education (NCE) Technical programme. The NCE Technical programme is a three year post-secondary education with an underlying philosophy which is to provide technical teachers with intellectual and professional background adequate for teaching technical subjects and to make them adaptable to any changing situation in technological development not only in the country but in the world at large (National Commission Colleges for Education (NCCE), 2002).

The study also became pertinent because for the philosophy of the NCE (Technical) programme to achieve its aim of accelerating scientific and technological development, students in technology and vocational training should be able to acquire manipulative skills through exposure to effective workshop practice instead of only theoretical teaching. Students exposed to effective practical training shall be able to utilize the knowledge acquired in the school workshop in their future employment in industries or factories that manufacture products related to their areas of specialization while at school. In essence, the practical training received by students in the school workshops should compare relatively with that of the industry where the trainee will subsequently work (Elobuike, 1998; and Duru, 2001).

Therefore, the school workshop environment should be conducive for students to exercise adequate and effective workshop practice as well as acquiring appropriate manipulative skills even when workshop spaces and the equipment/tools are provided. From the foregoing, study investigated the students' perception of thermal comfort in the school workshop as a stress factor affecting their task performance in workshop practice and used the Federal Colleges of Education, South-South Nigeria for the study.

Based on the purpose of the study, the following research question was formulated: To what extent do students perceive thermal discomfort in the school workshop as a stress factor affecting their task performance in workshop practice? Further, null hypothesis derived from the research question, a was postulated at 0.05 level of significance: There is no significant difference in the mean response scores of students from Federal College of Education (Technical), Asaba and Omoku respectively on the extent to which they perceive thermal discomfort in the school workshop as a stress factor affecting their task performance in workshop practice.

\section{Materials and Method}

\subsection{Study area}

The area of the study was the two Federal Colleges of Education (Technical) in South-South, Nigeria located at Asaba, Delta State and Omoku, Rivers State. They are geographically located along latitude $7^{\circ} \mathrm{N}$ and latitude $4^{\circ} \mathrm{S}$ in the warm tropical humid climatic region (Evans 1997). 


\subsection{Participants}

The population for the study was 185, 300 Level NCE Technical Education students in the two Federal Colleges of Education (Technical) at Asaba, Delta and Omoku, Rivers State. Data were obtained from the Schools of Technical Education during the 2008/2009 academic session and the population of 185 comprised 73 and 112 students from Asaba and Omoku respectively. The 300 Level students were chosen for the study because they offer the entire courses listed in the first and second years of the NCE programme before choosing an area of specialization in third year (NCCE, 2008). The colleges were funded by the Federal Government of Nigeria with common workshops used for workshop practice. The final year students are expected to have reasonable knowledge of workshop practice. No sample was taken because the population was manageable.

\subsection{Instrumentation}

The instrument for data collection was the Thermal Discomfort Perception and Task Performance Questionnaire (TDPTPQ). It was a structured questionnaire designed to collect data on students' perception responses of thermal discomfort in the school workshop as a stress factor affecting their task performance in workshop practice. It had four (4) questionnaire items in form of statements and had five (5) response options of Very great extent (VGE), Great extent (GE), Moderate extent (ME), Low extent (LE), and Very low extent (VLE) on a 5-point scale. The students were expected to choose from any of the options according to how they perceive the thermal discomfort stresses factors that affected their task performance in workshop practice.

The (TDPTPQ)) was administered to the 300 Level NCE Technical students of the Schools of Technical Education at the Federal Colleges of Education (Technical), Asaba and Omoku during the 2008/2009 academic session. The questionnaire for Omoku was administered by the researcher. A trained research assistant who teaches School Workshop Management administered that of Asaba because the course is offered by all 300 Level NCE Technical students who are expected to be in the lecture when the questionnaire was administered. The research assistant was instructed to tell the students the purpose of the study and to ask them to respond by ticking the options against the question items. The students were given a week or the next lecture period (the one that comes earlier) to submit the completed questionnaire to the research assistant. The researcher personally collected the completed questionnaire from the research assistant. Retrieval of questionnaire was 70 copies from students at Asaba out of 73 copies administered, representing $95.89 \%$; and 97 copies from students at Omoku out of 112 copies administered, and representing 86.60\%.

\subsection{Validation / reliability of the instrument}

The Thermal Discomfort Perception and Task Performance Questionnaire (TDPTPQ) was face-validated by professional colleague from the Federal College of Education (Technical), Omoku in order to ensure whether the items in the questionnaire were clear in wording, adequate and appropriate in addressing the problem and purpose of the study. The reliability of the instrument was tested by using thirty (30) 300 Level NCE Technical students from Federal College of Education (Technical), Umunze, Anambra State, Nigeria during the 2008/2009 academic session who were not part of the study. The college was used for the test because it runs the same NCE Technical Education programme. Further, the students would have had some reasonable knowledge of workshop practice and the use of various machines, equipment and power tools. The result of the Cronbach Alpha Coefficient test for the reliability of the TDPTPQ instrument was 0.85 , indicating the reliability of the instrument.

The arithmetic mean and standard deviation were used to establish the extent to which the students perceived thermal discomfort in the school workshop as a stress factor affecting task performance in workshop practice. The hypothesis was tested with Z-test of independent group means at a significance level of 0.05 levels for two tailed test to establish whether there was no significant difference in the mean perception responses of students from the Federal Colleges of Education (Technical), Asaba and their counterparts from Omoku on the extent to which thermal discomfort in school workshop as a stress factor affected their task performance in workshop practice.

On a 5-point scale, the decision rule assigned to students' responses were; very great extent, (4.50-5.00); great extent, (3.50-4.49); moderate extent, (2.50-3.49); low extent, (1.50-2.49); and very low extent, (1.00-1.49). In addition, where the Z-calculated value in the null hypothesis is equal to or greater than the critical table value, reject the null hypothesis and if it is otherwise, do not reject it. 


\section{Results}

The results of the research question on the extent to which students perceive thermal discomfort in the school workshop as a stress factor affecting their task performance in workshop practice presented in Table 1 indicated the students' Grand Perception Mean responses (xG) of 3.85 and 3.97 for Federal College of Education (Technical), Asaba and their counterparts from Omoku.

Table 1. Students' mean perception responses on thermal discomfort as a stress factor affecting their task performance in workshop practice

\begin{tabular}{|l|c|c|c|c|c|}
\hline \multicolumn{1}{|c|}{ Noise stress indicators } & \multicolumn{2}{|c|}{ Asaba } & \multicolumn{2}{c|}{ Omoku } & \multirow{2}{*}{ Decision } \\
\cline { 2 - 5 } & $\mathrm{X}_{\mathrm{A}}$ & $\mathrm{SD}_{\mathrm{A}}$ & $\mathrm{X}_{0}$ & $\mathrm{SD}_{0}$ & Great \\
\hline $\begin{array}{l}\text { Thermal discomfort causes mental fatigue (lack of concentration) which affects } \\
\text { cognitive motor tasks. }\end{array}$ & 4.21 & 1.05 & 4.30 & 0.95 & $\begin{array}{r}\text { Greant } \\
\text { extent }\end{array}$ \\
\hline Thermal discomfort causes inattentiveness which affects reaction time. & 3.66 & 0.95 & 3.97 & 1.02 & $\begin{array}{c}\text { Great } \\
\text { extent }\end{array}$ \\
\hline Thermal discomfort causes non-vigilance which affects precision tasks & 3.78 & 1.07 & 3.90 & 1.06 & $\begin{array}{c}\text { Great } \\
\text { extent }\end{array}$ \\
\hline $\begin{array}{l}\text { Thermal discomfort causes physical fatigue (tiredness) which affects someone's control } \\
\text { of the work environment. }\end{array}$ & 4.09 & 1.18 & 4.12 & 1.12 & $\begin{array}{r}\text { Great } \\
\text { extent }\end{array}$ \\
\hline $\begin{array}{l}\text { Thermal discomfort causes restlessness which affects task performance requiring great } \\
\text { attention. }\end{array}$ & 3.53 & 1.18 & 4.12 & 0.92 & $\begin{array}{r}\text { Great } \\
\text { extent }\end{array}$ \\
\hline Grand mean $\left(\mathrm{X}_{\mathrm{G}}\right)$ & 3.85 & 1.09 & 4.08 & 1.01 & $\begin{array}{r}\text { Great } \\
\text { extent }\end{array}$ \\
\hline
\end{tabular}

That is, thermal discomfort in the school workshop as a stress factor affected their task performance in workshop practice to a great extent when they responded to the thermal discomfort stress indicators namely: mental fatigue (lack of concentration), inattentiveness, non-vigilance, physical fatigue (tiredness) and restlessness. The Grand Mean Standard Deviations $\left(\mathbf{x}_{\mathbf{G}}\right)$ of 1.09 and 1.01 for the students' perception scores from Asaba and Omoku were small; not widely dispersed but clustered and close to the mean. This revealed that, the students' perception scores had a small variability and therefore homogeneous.

The results of the hypothesis presented in Table 2 revealed that there was no significant difference in the mean perception responses of students from Federal College of Education (Technical), Asaba and students from Federal College of Education (Technical), Omoku on the extent to which thermal discomfort in the school workshop as a stress factor affected their task performance in workshop practice.

Table 2. Z-test for mean perception responses of students on thermal discomfort as a stress factor affecting their task performance in workshop practice

\begin{tabular}{|c|c|c|c|c|c|c|c|c|}
\hline Colleges & $\mathrm{N}$ & $\mathrm{X}$ & $\mathrm{SD}$ & $\mathrm{Df}$ & $\mathrm{P} \leq$ & Z-calculated & Z-critical & Decision \\
\hline Asaba & 70 & 3.85 & 1.09 & \multirow{2}{*}{165} & 0.05 & 1.35 & 1.65 & $\begin{array}{c}\text { Not significant } \\
\text { Ho: not rejected }\end{array}$ \\
\hline Omoku & 97 & 4.08 & 1.01 & & & &
\end{tabular}

The results further indicated that, the Z-calculated of 1.35 was less than the Z-critical value of 1.65; and the null hypothesis was therefore not rejected at $\mathrm{P} \leq 0.05$.

\section{Discussion}

From the results of the findings, the students perceived that thermal discomfort in school workshop due to high temperature and relative humidity, and low wind velocity which caused mental fatigue (lack of concentration), nonvigilance, physical fatigue (tiredness) and restlessness, affected their task performance in cognitive and motor tasks; precision tasks; tasks requiring greater attention, and reaction time. In line with this finding, Basu, Sahu \& Datta (2006); Kolarik, Toftum, Olesen \& Shitzer (2009); and Kwon, Adam \& Tang (2009) opined that, thermal discomfort adversely affected productivity in physical and mental tasks because discomfort from climatic factor creates competition for blood between the working muscles and the skin which leads to exhaustion in physical activities and performance decrement 
occurs sooner in hot environment. Ramsey \& Kwon (1988); and Basu, Sahu \& Datta (2006) further reported that investigations into thermal comfort performance showed that, at higher temperatures and humidity, and low air movement, there was relative decrement in task performance in both physical and mental tasks in terms of total work cycle/mm; impaired motor/manual performance; and variability (wider distribution of test scores) in performance.

In addition, there was no significant difference in the mean perception responses of students from the two Colleges at Asaba and Omoku on the extent to which thermal discomfort in school workshops as a stress factor affecting their task performance in workshop practice. The perception of the two groups of students was not likely to differ significantly because the two colleges of Education (Technical) at Asaba and Omoku are located in the same tropical humid climatic region that is characterized by high temperature and relative humidity, and low wind velocity. The two colleges lie between latitude $7^{0} \mathrm{~N}$ and $4^{0} \mathrm{~S}$ with minimum and maximum temperature between $29^{\circ} \mathrm{C}$ and $36^{\circ} \mathrm{C}$; minimum and maximum relative humidity between $62 \%$ and $87 \%$; and wind velocity between $0.23 \mathrm{~m} / \mathrm{s}$ and $0.39 \mathrm{~m} / \mathrm{s}$ (NIMET, 2004). From the foregoing students carrying out workshop practice in both colleges experienced high temperature and relative humidity; and low wind velocity. The consequence was that, the internal room temperature and humidity increased through excessive heat generated by the machines/equipment; and vapour liberated by the students as a result of the vigorous workshop activities especially when the workshop space lacked adequate ventilation. The students therefore, felt heat sensation and "wettedness" since the atmosphere in the internal room was saturated with moisture, and the low evaporation of sweat from the perspiring students occasioned by low wind velocity of between $0.23 \mathrm{~m} / \mathrm{s}$ and $0.39 \mathrm{~m} / \mathrm{s}$ did not provide for effective and pleasant cooling effect (Burberry, 1997). Thus, the thermal comfort of the students was affected and consequently their task performance was also affected since it was the combination of high temperature and relative humidity, and low wind velocity that brought about the thermal discomfort stress-behaviours such as lack of concentration, tiredness, inattentiveness and restlessness.

\section{Conclusions}

From the findings of the study, the students at Federal College of Education (Technical), Asaba and Omoku perceived that thermal discomfort in school workshops as a stress factor to a great extent affected their task performance in workshop practice. Further, the mean perception responses of the students from the Federal College of Education (Technical), Asaba and their counterparts from Omoku did not differ significantly on the extent to which thermal discomfort affected their task performance in workshop practice. It was therefore concluded from the findings of this study that, thermal discomfort affected students' task performance in workshop practice at the Federal Colleges of Education South-South, Nigeria.

Based on the findings of the study, it was recommended that thermal discomfort conditions in the workshop space should be minimized to enhance students' task performance in workshop practice. To achieve this, the workshop space should not be overcrowded; external window opening should be in proportion with the external wall area; workshop buildings should be properly oriented with façades that have greater number of windows placed in the direction of prevailing wind to admit adequate air into the room space; and external windows should be protected with adequate overhangs to preclude the admission of unwanted solar radiation.

\section{References}

Adler, G. D. (1997). Thermal comfort. In P. Tutt and D. Adler (Eds.), New Metric Handbook. Butterworth-Heinemann, London. $402-411$ Anyakoha, M. W. (2006). New school physics low senior secondary schools. Africana First Publishers Ltd, Onitsha, Nigeria: Ayoade, J. 0. (2002). Introduction to climatology for the tropics. Spectrum Books Ltd, Ibadan Basu, S. K; Sahu, K. C. \& Datta, N. K (2006). Works organization and management. Oxford and IBH Publishing Co. Pvt Ltd, Delhi Bell, P. A.; Greene, T .C; Fisher, J. D; \& Baum, A. (2005). Environmental psychology. Routledge, Taylor and Francis Group, New York Blum, M. L. \& Naylor, J. C. (2004). Industrial psychology: Its theoretical and social foundations. CBS Publishers \& Distributors, New Delhi.

Burberry. P. (1997). Environment and services. B. T Batsford, London.

Chardderton, D. V. (2007). Building services engineering. E \& FN Spon, London.

Dagostino, F. R. (2004). Mechanical and electrical systems in construction and architecture. Reston Publishing Company Inc., Reston, Virginia.

Duru, D. D. (2001). Achieving effective woodwork practice in technical institutions in Nigeria. Studies in Technical Teacher Education. 4(1), 23- 28.

Elobiuke, H. U. (1998). Organization and administration of vocational education. Unpublished lecture manual. Enugu State University of Science and Technology. 
Evans, M. (1997). Tropical design. In P. Tutt and D. Adler (Eds.), New Metric Handbook. Butterworth-Heinemann, London. $402-411$ Fanger, P.O. (1982). Thermal comfort. McGraw-Hill Book Company, New York.

Givoni, B. (1981). Man, climate and architecture. Applied Science Publishers Ltd, London.

Hammer, W \& New Jersey: Price, D. (2002). Occupational safety management and engineering. Prentice Hall Inc., New Jersey

Hornby, A. S. (2006). Oxford advanced learner's dictionary. Oxford University Press, Oxford.

Jain, R. K \& Rao, S. S. (2006). Industrial safety, health and environment management systems. Khanna Publishers, Delhi.

Kavianian, H. R. \& Wentz, C.A. (1996). Occupational and environmental safety engineering and management. Van Nostrand Reinhold, New York

Kolarik, J; Toftum, J; Olesen, B. W; \& Schitzer, A. (2009). Occupants' responses and office work performance in environments with moderately drifting operative temperatures (RP-1269). HVAC \& R Research. 15(5), 931-960.

Kwong, Q. J; Adam. N. M. \& Tang, S. H. (2009). Effect of environmental comfort factors in enclosed transitional space toward work productivity. American Journal of Environmental sciences. Retrieved from www.thefreelibrazy com

Markus, T. A. \& Morris, E. (1980). Building, climate and energy. Pitman Publishing Ltd, London

NCCE, (2008). Minimum standards for Nigeria Certificate in Education: School of vocational and technical education. National Commission for Colleges of Education, Abuja.

NIMET, (2010). Nigerian Meteorological Agency. Nigeria: Federal Ministry of Science and Technology, Abuja.

Ramsey, J; Bufford, C; Beshir, M \& Jensen, R. (1983). Effect of workplace conditions on safe work behaviuors. Journal of Safety Research. 14, 105-114

Ramsey, J \& Kwon, Y (1988). Simplified decision rules for predicting performance loss in heat. Proceedings on heat stress indices. Luxemburg: Commission of European Communities.

Sanders, M. S. \& McCormick, E .J. (1993). Human factors in engineering and design. McGraw-Hill Inc., New York.

Yaglou, C .P. (1968). Indices of comfort. In L. H. Newburgh (Ed.). Physiology of heat regulation and the science of clothing. 268

Yellot, J. I. (2003). Thermal comfort design. In G. Ramsey \& H. R. Sleeper (Eds). Ramsey/Sleeper architectural graphics Standards. John Wiley \& Sons Inc., New York. Pp 65 
